\title{
PERLINDUNGAN HUKUM BAYI MELALUI PEMBERIAN \\ ASI EKSKLUSIF DALAM PRESPEKTIF \\ UNDANG-UNDANG NOMOR 36 TAHUN 2009 TENTANG KESEHATAN*
}

\author{
${ }^{*}$ Edy Nurcahyo ${ }^{1}$, Siti Khuzaiyah ${ }^{2}$ \\ Program Studi Ilmu Hukum, Fakultas Hukum, Universitas Muhammadiyah Buton ${ }^{1}$ \\ *e-mail: edy.nurcahyo@umbuton.ac.id, \\ Program Studi DIII Kebidanan STIKES Muhammadiyah Pekajangan Pekalongan ${ }^{2}$ \\ e-mail: khuzaiyahmidwive@gmail.com
}

\begin{abstract}
The legal research aims to describe legal protection for exclusive breastfeeding for babies in the prespective of Law Number 36 of 2009 concerning Health. The research method is normative legal research. The main data source used is literature. The author uses the statutory approach because it adapts to the legal material being studied, then analyzed with qualitative analysis. The result of the study shows that legal protection for exclusive breastfeeding for infants has obtained public law protection. Indonesia has implemented the International Code of Marketing of Breastfeeding-Milk Substitutes through a national policy to support the exclusive breastfeeding program, namely by the prohibition of advertising of infant formula milk either through print or electronic media.
\end{abstract}

Keyword: Legal Protection, Baby, Exclusive Breastfeeding,

\begin{abstract}
Abstrak
Penelitian hukum ini bertujuan untuk mendeskripsikan perlindungan hukum atas pemberian ASI eksklusif terhadap bayi dalam prespektif Undang-Undang Nomor 36 Tahun 2009 Tentang Kesehatan. Metode penelitian ini adalah penelitian hukum normatif (normative legal research), sumber data utama yang digunakan adalah data kepustakaan atau literatur. Penulis menggunakan pendekatan perundang-undangan (statute approach) karena menyesuaikan dengan bahan hukum yang diteliti, selanjutnya dianalisis dengan analisis kualitatif. Hasil penelitian menunjukkan bahwa perlindungan hukum atas pemberian ASI eksklusif terhadap bayi telah mendapatkan perlindungan hukum publik. Indonesia sudah menerapkan International Code of Marketing of Breast-Milk Substitutes melalui kebijakan nasional untuk mendukung program pemberian ASI Eksklusif yaitu dengan adanya larangan iklan susu formula bayi baik melalui media cetak ataupun media elektronik.
\end{abstract}

Kata Kunci: Perlindungan Hukum, Bayi, ASI Ekslusif

\footnotetext{
* Naskah diterima: 13 Agustus 2018, direvisi: 13 Agustus 2018, disetujui untuk terbit: 25 September 2018
} 
Edy Nurcahyo dan Siti Khuzaiyah: Perlindungan hukum bayi melalui pemberian Asi...

\section{PENDAHULUAN}

Cita-cita bangsa Indonesia adalah mewujudkan kesejahteraan bagi seluruh rakyat sebagaimana termaktub dalam Pancasila dan Undang-Undang Dasar Negara Republik Indonesia Tahun 1945 (UUD NRI 1945), salah satu unsur penting dalam membangun kesejahteraan diantaranya adalah kesehatan masyarakat. Meningkatkan derajat kesehatan masyarakat sangatlah penting dalam rangka pembentukan Sumber Daya Manusia (SDM) Indonesia yang unggul dan berdaya saing global. Oleh karena itu segala bentuk yang menyebabkan terjadinya gangguan kesehatan pada masyarakat Indonesia harus disingkirkan agar tidak menimbulkan kerugian yang besar. Peningkatan derajat kesehatan itu sendiri harus sesuai dengan prinsif nondiskriminasi, partisipatif, dan berkelanjutan. Sementara itu, upaya peningkatan derajat kesehatan dipersepsikan sebagai investasi bagi pembangunan Negara. Pembangunan Negara tidak lagi dipersepsikan dengan hanya pembangunan fisik saja, pembangunan non-fisik seperti kesehatan turut menjadi pondasi yang kokoh untuk membangun kemajuan di berbagai bidang. Sehingga menjadi hal yang patut dalam pembangunan nasional harus memperhatikan kesehatan masyarakat (Konsederan UU No. 36 Tahun 2009 tentang Kesehatan).

Arti penting kesehatan juga dituangkan di dalam Rencana Pembangunan Jangka Panjang Nasional (RPJP-N). Pembangunan kesehatan menurut RPJP-N 2005-2025 diarahkan untuk meningkatkan derajat kesehatan masyarakat melalui berbagai upaya seperti peningkatan upaya kesehatan (Yenny Fitri.Z, 2018: 273).

Saat ini, Indonesia membutuhkan generasi muda yang berkualitas agar mampu bersaing sekaligus menjadi generasi bangsa yang unggul dalam menghadapi persaingan antar bangsa di dunia mengingat semakin kompetitifnya persaingan tersebut. Oleh sebab itu, generasi bangsa yang berkualitas itu terwujud apabila anak-anak sejak dalam kandungan, saat lahir, dan dalam masa pertumbuhannya dapat terpenuhi dengan baik gizinya, sehingga mereka dapat tumbuh dan berkembang dengan sehat, kuat dan cerdas (Kemenkes RI, 2017: 1).

Periode tiga tahun pertama pada masa balita merupakan periode emas pertumbuhan fisik, intelektual, mental, emosional, dan spiritual anak. Bahkan untuk meningkatkan dan mengoptimalkan kualitas hidup anak agar menjadi generasi bangsa yang cerdas sudah semestinya mendapatkan perhatian penuh pada periode tiga tahun pertama itu diantaranya adalah pemberian ASI secara eksklusif, gizi yang baik, imunisasi, vitamin dan pelayanan kesehatan yang bermutu, serta kasih sayang dan stimulasi yang memadai (Depkes RI, 2011: 1).

Dalam rangka menurunkan angka kesakitan dan kematian anak, United Nation Childrens Fund (UNICEF) dan World Health Organization (WHO) merekomendasikan sebaiknya anak hanya disusui air susu ibu (ASI) selama paling 
sedikit enam bulan. Makanan padat seharusnya diberikan sesudah anak berumur enam bulan, dan pemberian ASI dilanjutkan sampai anak berumur dua tahun (WHO, 2005) (Coetzee, L., Montshwe, B.D. and Jooste, A., 2004: 2).

Pemberian air susu ibu (ASI) eksklusif untuk bayi telah diatur dalam Undang-Undang Kesehatan (UU No. 36 Tahun 2009 Tentang Kesehatan). Namun pada era perkembangan teknologi saat ini, banyak perusahaan susu formula yang menawarkan produknya untuk konsumsi bayi. Hal ini dapat menimbulkan sebuah konflik kepentingan antara perintah Undang-Undang yang mewajibkan memberikan air susu ibu (ASI) eksklusif kepada bayi dalam periode usia tertentu dengan kebutuhan perusahaan pemasaran susu formula untuk memasarkan produknya sebagai konsumsi bayi.

Pasal 129 Undang-Undang No. 36 tentang kesehatan menyebutkan bahwa Pemerintah bertanggung jawab menetapkan kebijakan dalam rangka menjamin hak bayi untuk mendapatkan air susu ibu secara eksklusif.

Hak bayi untuk mendapatkan ASI eksklusif diatur dalam Pasal 28 ayat (1) berbunyi:

"Setiap bayi berhak mendapatkan air susu ibu eksklusif sejak dilahirkan selama 6 (enam) bulan, kecuali atas indikasi medis."

Namun pada realitanya, banyak bayi tidak mendapatkan haknya secara penuh. Tidak terpenuhinya hak bayi dalam mendapatkan ASI secara eksklusif disebabkan beberapa faktor kendala.
Faktor kendala yang menjadi penghalang bagi bayi untuk mendapatkan ASI eksklusif diantaranya adalah: (1) Ibu kurang memahami tata laksana laktasi yang benar; ( 2) Produksi ASI kurang, bayi terlanjur mendapatkan prelacteal feeding (air gula atau formula) pada hari pertama kelahiran; (3) Kelainan puting ibu; (4) Kesulitan bayi dalam menghisap; (5) Ibu hamil lagi saat masih menyusui; (6) Ibu bekerja sehingga harus meninggalkan bayinya di rumah; (7) Keinginan untuk disebut modern; dan (8) Pengaruh iklan susu formula yang kian gencar (Nurlaili Susanti, 2011:166-167)

Problematika tidak terpenuhinya hak bayi dalam mendapatkan ASI eksklusif telah menjadi perhatian Organisasi Kesehatan Dunia (WHO) dan juga pemerintah Indonesia, mengingat kepentingan bayi dalam mendapatkan ASI eksklusif maka perlu mendapatkan perlindungan hukum. Oleh karena itu dalam penelitian ini ingin menjawab bagaimana perlindungan hukum terhadap bayi dalam pemberian susu eksklusif?, dan bagaimana pengaturan hukum kesehatan dalam pemberian air susu ibu (ASI) eksklusif? Mengingat ada kepentingan bisnis yang mungkin turut menjadi penghalang bagi hak bayi untuk mendapatkan air susu ibu (ASI) secara eksklusif. Oleh karena itu peneliti memilih judul "perlindungan hukum bayi melalui pemberian ASI eksklusif dalam prespektif Undang-Undang Nomor 36 tahun 2009 Tentang Kesehatan."

\section{METODE PENELITIAN}


Edy Nurcahyo dan Siti Khuzaiyah: Perlindungan hukum bayi melalui pemberian Asi...

Dalam penelitian hukum ini, penulis menggunakan penelitian hukum normatif. Adapun pendekatan yang digunakan yaitu pendekatan perundang-undangan (statute approach), yaitu dengan menganalisis dan mengkaji peraturan perundangundangan yang berkaitan dengan kesehatan khususnya pemberian ASI eksklusif terhadap bayi kemudian mendeskripsikannya. Dalam penelitian ini, pengkajian yang dilakukan hanyalah "terbatas" pada data sekunder yang diperoleh dari bahan kepustakaan atau literature yang mempunyai hubungan dengan objek yang diteliti. Adapun analisis data yang digunakan yaitu analisis kualitatif.

\section{HASIL DAN PEMBAHASAN}

\section{Regulasi pemberian ASI Eksklusif di Indonesia}

Setelah terbitnya resolusi tentang nutrisi pada Sidang Kesehatan Dunia (WHA) ke Lima Puluh Sembilan, Indonesia telah membuat regulasi pemberian air susu ibu dan pelarangan iklan susu formula bayi.

Sidang Kesehatan Dunia (World Health Assembly) ke Lima Puluh Sembilan, dilaksanakan di Jeneva pada tanggal 22-27 Mei 2006 dengan dihadiri 192 negara anggota WHO. Hasil resolusi tersebut berisi desakan kepada global untuk mengakhiri promosi produk makanan bayi dan anak yang tidak selayaknya. Pemerintah Indonesia juga telah mengeluarkan kebijakan berkaitan pemberian air susu ibu dan larangan iklan susu formula bayi yang diatur dalam
Undang-Undang Nomor 36 Tahun 2009 tentang Kesehatan dan Peraturan Pemerintah Nomor 33 Tahun 2012 tentang Pemberian Air Susu Ibu Eksklusif.

Tujuan pengaturan pemberian ASI Eksklusif dalam Peraturan Pemerintah Nomor 33 Tahun 2012 tentang Pemberian Air Susu Ibu Eksklusif adalah sebagai berikut: (1) Menjamin pemenuhan hak Bayi untuk mendapatkan ASI Eksklusif sejak dilahirkan sampai dengan berusia 6 (enam) bulan dengan memperhatikan pertumbuhan dan perkembangannya; (2) Memberikan perlindungan kepada ibu dalam memberikan ASI Eksklusif kepada bayinya; dan (3) Meningkatkan peran dan dukungan keluarga, masyarakat, Pemerintah Daerah, dan Pemerintah terhadap pemberian ASI Eksklusif.

Hal yang menjadi pertimbangan perlunya regulasi yang mengatur tentang pemberian Air Susu Ibu secara eksklusif terhadap bayi yaitu: (1) Air Susu Ibu (ASI) merupakan makanan terbaik untuk bayi karena mengandung zat gizi paling sesuai untuk pertumbuhan dan perkembangan bayi; (2) Agar pertumbuhan dan perkembangan bayi dapat mencapai optimal maka ASI perlu diberikan secara eksklusif sampai umur 6 (enam) bulan dan dapat dilanjutkan sampai anak berumur 2 (dua) tahun;

Ditinjau dari perkembangan terbentuknya peraturan perundangundangan yang mengatur dan/atau mendukung pemberian ASI Eksklusif terhadap bayi, adalah sebagai berikut: (1) Undang-Undang Nomor 23 Tahun 1992 
tentang Kesehatan; (2) Keputusan Menteri kesehatan Nomor 450/Menkes/SK/IV/ 2004 tentang Pemberian Air Susu Ibu secara Eksklusif; (3) Undang-Undang Nomor 36 Tahun 2009 tentang Kesehatan; (4) Peraturan Pemerintah Nomor 33 Tahun 2012 tentang Pemberian Air Susu Ibu Eksklusif.

\section{Perlindungan Hukum Atas Pemberian ASI Eksklusif Terhadap Bayi}

Di Indonesia, perlindungan hukum atas pemberian ASI Eksklusif terhadap bayi, telah mendapatkan perhatian serius dari semua kalangan baik pemerintah maupun elemen masyarakat. Bukti adanya perlindungan hukum atas pemberian ASI Eksklusif terhadap bayi adalah sebagai berikut: (1) Pemerintah Indonesia telah membuat dan melaksanakan kebijakan nasional dalam rangka pemberian ASI Eksklusif; (2) Adanya tanggung jawab pemerintah dalam menetapkan kebijakan dalam rangka menjamin hak bayi untuk mendapatkan air susu ibu secara eksklusif (Pasal 129 ayat (2) UU No 36 Tahun 2009 tentang Kesehatan); (3) Adanya peraturan pemerintah nomor 33 Tahun 2012 tentang Pemberian Air Susu Ibu Eksklusif; (4) Adanya kewajiban bagi setiap perusahaan tempat ibu bekerja harus menyediakan ruang laktasi khusus untuk memberikan ASI Eksklusif atau memerah susu untuk disimpan.

Bila ditinjau dari prespektif Hak Asasi Manusia (HAM), mendapatkan Air Susu Ibu (ASI) merupakan salah satu hak asasi bayi yang wajib dijamin dan dilindungi secara hukum.
Di Indonesia yang masyarakatnya mayoritas muslim, agama membantu mempengaruhi kesadaran akan pentingnya pemberian air susu ibu (ASI) terhadap bayi selama 2 (dua) tahun penuh, untuk yang ingin memberikan ASI secara sempurna. Dalam Kitab Suci Al-Qur'an anjuran untuk memberikan ASI secara eksklusif termaktub dalam surat AlBaqarah ayat 233:

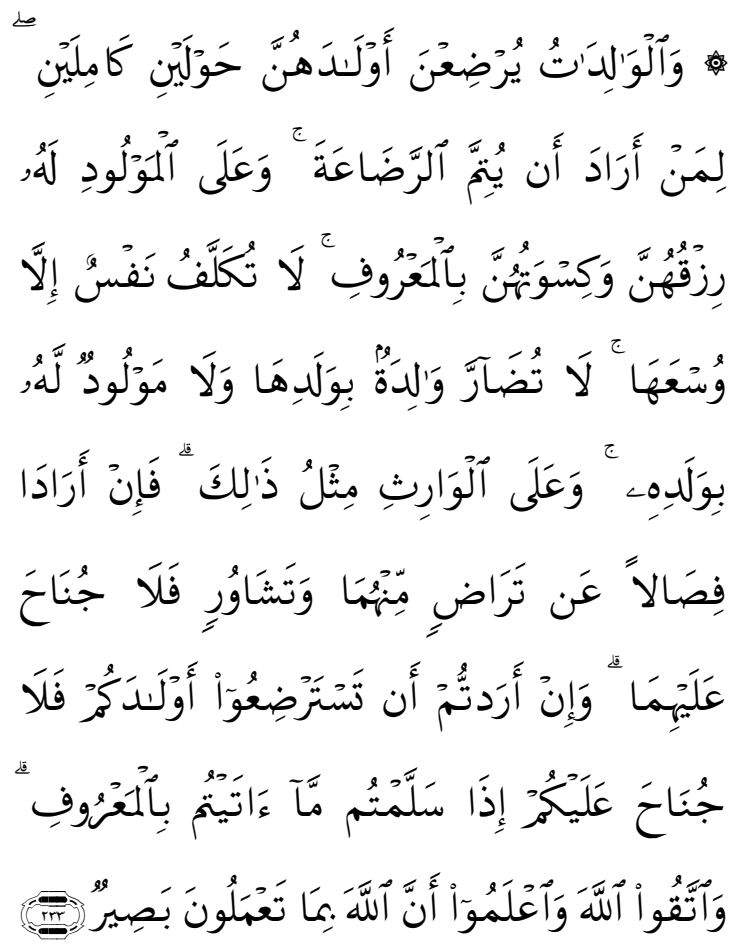

Terjemahannya: "Para ibu hendaklah menyusukan anak-anaknya selama 2 (dua) tahun penuh, bagi yang ingin menyusui secara sempurna. Dan kewajiban ayah menanggung nafkah dan pakaian mereka dengan cara yang patut. Seseorang tidak dibebani lebih dari kesanggupannya. Janganlah seorang ibu menderita karena anaknya dan jangan pula seorang ayah (menderita) karena anaknya. Ahli waris pun (berkewajiban) seperti itu pula. Apabila keduanya ingin menyapih dengan persetujuan dan permusyawaratan antara keduanya, maka tidak ada dosa atas keduanya. Dan jika kamu ingin menyusukan anakmu kepada orang lain, maka tidak ada dosa bagimu 
Edy Nurcahyo dan Siti Khuzaiyah: Perlindungan hukum bayi melalui pemberian Asi...

memberikan pembayaran dengan cara yang patut. Bertakwalah kepada Allah dan ketahuilah bahwa Allah Maha Melihat apa yang kamu kerjakan".

Dengan adanya anjuran dalam AlQuran mengenai keharusan untuk menyempurnakan pemberian ASI secara penuh selama 2 (dua) tahun, itu menunjukkan betapa sangat pentingnya pemberian ASI untuk bayi.

Ulasan mengenai hak anak telah diuraikan dalam undang-undang perlindungan anak, dapat dipahami bahwa hak anak menjadi bagian dari hak asasi manusia yang keberadaannya harus dilindungi dan dipenuhi oleh semua pihak termasuk oleh kedua orang tuanya, keluarga, masyarakat maupun pemerintah dan Negara (Pasal 1 nomor 12 UU No. 35 Tahun 2014). Hak anak tersebut mencakup (1) non diskriminasi; (2) kepentingan terbaik bagi anak; (3) hak kelangsungan hidup; dan (4) perkembangan dan penghargaan terhadap pendapat anak.

Pemberian ASI Eksklusif terhadap bayi merupakan salah satu kepentingan terbaik bagi bayi. Telah banyak hasil penelitian berkaitan dengan manfaat ASI Ekslusif yang telah dipublikasikan keseluruhan dunia, namun angka cakupan ASI Eksklusif masih jauh dari yang diharapkan. Hanya $39 \%$ bayi dibawah enam bulan mendapatkan ASI Eksklusif pada tahun 2012. Angka global ini hanya meningkat dengan sangat perlahan selama beberapa dekade terakhir (Prabasiswi, A., Fikawati, S., S., Syafiq, A., 2014: 282).
Perlindungan yang diberikan kepada bayi untuk mendapatkan ASI secara Eksklusif merupakan bentuk perlindungan khusus yaitu suatu bentuk perlindungan yang diterima oleh bayi/anak dalam situasi dan kondisi tertentu untuk mendapatkan jaminan rasa aman terhadap ancaman yang membahayakan diri dan jiwa dalam tumbuh kembangnya.

Menurut Theresia Geme, perlindungan hukum merupakan tindakan Negara untuk melakukan sesuatu dengan (memberlakukan hukum Negara secara eksklusif) dengan tujuan untuk memberikan jaminan kepastian hak-hak seseorang (Maria Theresia Geme, 2012: 99). Menggunakan pendekatan teori perlindungan hukum tersebut dapat dipahami bahwa Negara telah memberikan jaminan hak bagi bayi untuk mendapatkan haknya berupa pemberian ASI eksklusif melalui UU No. 36 Tahun 2009 Tentang Kesehatan dan PP No. 33 Tahun 2012 Tentang Pemberian Air Susu Ibu Eksklusif.

Sementara itu menurut Satjipto Raharjo, perlindungan hukum merupakan upaya memberikan pengayoman terhadap hak asasi manusia (HAM) yang dirugikan orang lain dan perlindungan tersebut diberikan kepada masyarakat agar dapat menikmati semua hak-hak yang diberikan oleh hukum (Satjipto Raharjo, 2000: 54). Bilamana dianalisis menggunakan pendekatan teori perlindungan hukum ini, secara eksplisit disebutkan dalam UU No. 36 Tahun 2009 pada Pasal 128 ayat (1) "Setiap bayi berhak mendapatkan air susu ibu eksklusif sejak dilahirkan selama 6 
(enam) bulan...." maka bayi telah mendapatkan jaminan kepastian hak berupa pemberian ASI eksklusif dimana negara turut hadir untuk melindungi haknya.

Menurut Salim HS, perlindungan merupakan "upaya atau bentuk pelayanan yang diberikan oleh hukum kepada subjek hukum serta hal-hal yang menjadi objek yang dilindungi" (Salim HS \& Erlies SN, 2013: 99). Dapat dipahami bahwa subjek yang mendapat jaminan pemenuhan hak adalah bayi dan ibu bayi, dan hal yang menjadi objek perlindungan adalah pemberian ASI eksklusif.

Secara teoritis, bentuk perlindungan hukum dibagi menjadi dua bentuk, yaitu: (1) Perlindungan yang bersifat Preventif; dan (2) Perlindungan Represif (Phillipus M Hadjon, 1987, hal 2). Perlindungan yang diberikan kepada bayi dalam pemberian ASI eksklusif adalah bentuk perlindungan hukum preventif. Perlindungan hukum yang sifatnya preventif diberikan agar bayi dapat terpenuhi haknya untuk mendapatkan ASI secara eksklusif agar tercegah dari segala resiko kesehatan.

\section{Kode (Etik) Internasional Pemasaran Pengganti Air Susu Ibu (International Code of Marketing of Breast-Milk Substitutes)}

Munculnya Kode Etik Internasional Pemasaran Pengganti Air Susu Ibu dilatarbelakangi oleh keprihatinan menurunnya penggunaan ASI terhadap bayi. Pada tahun 1974, Persidangan Dewan Kesehatan Dunia ke Dua Puluh
Tujuh mencatat adanya penurunan dalam pemberian ASI di beberapa bagian kawasan dunia, yang berkaitan dengan faktor sosial budaya dan faktor sosial dan cultural dan faktor lainnya, termasuk promosi makanan pengganti ASI pabrikan, dan mendesak "Negara-negara anggota untuk mengkaji kembali kegiatan-kegiatan promosi penjualan makanan bayi untuk memperkenalkan upaya-upaya perbaikan, termasuk kode etik pengiklanan dan legislasi bila mana dipandang perlu (WHO Geneva, 1981: 4).

Pada Persidangan Dewan Kesehatan Dunia ke Tiga Puluh Tiga pada bulan Mei 1978, masalah tersebut kembali dibahas, dan diantara rekomendasinya adalah bahwa Negara-negara anggota hendaknya memberikan perioritas pada pencegahan malnutrisi di kalangan bayi dan anakanak, diantaranya dengan mendukung dan mempromosikan pemberian ASI dengan bekerja sama dengan para ibu, dan mengatur "promosi penjualan makanan bayi yang tidak patut yang dapat digunakan untuk menggantikan air susu ibu." (WHO Geneva, 1981: 5).

Akhirnya, pada penghujung tahun 1978, WHO dan UNICEF mengumumkan niatnya untuk menyelenggarkan pertemuan bersama mengenai pemberian makanan bagi bayi dan anak-anak, di dalam program-program mereka, untuk mencoba memanfaatkan pendapat yang sangat mendasar itu dengan sebaikbaiknya. Setelah melalui pertimbangan yang saksama mengenai bagaimana memastikan partisipasi yang tinggi, pertemuan diselenggarakan di Jenewa dari 
Edy Nurcahyo dan Siti Khuzaiyah: Perlindungan hukum bayi melalui pemberian Asi...

tanggal 9 sampai 12 Oktober 1979, dan dihadiri oleh sekitar 150 perwakilan dari kalangan pemerintah, organisasiorganisasi di bawah sistem Perserikatan Bangsa-Bangsa (PBB), dan badan-badan antar pemerintah yang lain, organisasi non-pemerintah, kalangan industri makanan bayi, dan para ahli dalam disiplin ilmu terkait. Diskusi-diskusi diselenggarakan dibawah lima tema: dorongan dan dukungan pemberian ASI; promosi dan dukungan praktek-praktek pemberian makanan (sapih) pelengkap pada saat yang sesuai dan tepat waktu dengan menggunakan sumber-sumber makanan setempat; pemantapan komunikasi, edukasi, dan informasi (KEI) mengenai pemberian makanan bayi dan anak-anak; promosi status kesehatan dan sosial perempuan dalam hubungannya dengan pemberian makanan dan kesehatan bayi dan anak-anak; dan pemasaran \& distribusi makanan pengganti ASI (WHO, 1981: 5).

\begin{tabular}{lrlr}
\multicolumn{2}{c}{ Organisasi } & \multicolumn{2}{l}{ Kesehatan sedunia } \\
(WHO) pada & tahun 1981 telah
\end{tabular} mengeluarkan kode etik pemasaran susu pengganti ASI. Menyelamatkan bayi serta melindungi program pemberian ASI secara eksklusif menjadi salah satu tujuan kode etik tersebut agar terhindar dari tindakan pemasaran dari produsen yang dapat mempengaruhi perilaku ibu dan keluarga yang memiliki dampak negatif berupa mengesampingkan pemberian ASI secara eksklusif karena lebih memilih susu formula. Ringkasan dari kode etik tersebut yaitu: (1) Melarang pemberian sampel gratis; (2) Melarang promosi di tempat fasilitas kesehatan; (3) Melarang konseling langsung dengan publik; (4) Memberikan hadiah kepada petugas kesehatan; (5) memuat gambar bayi; (6) Label harus mencantumkan keuntungan ASI (Briawan, Dodik, 2004: 8-9).

\section{Larangan Iklan Susu Formula}

Setiap ibu yang melahirkan wajib memberikan ASI Eksklusif kepada bayi yang dilahirkannya, namun kewajiban tersebut memiliki pengecualian sebagai mana diatur dalam Pasal 7 PP No. 33 Tahun 2012 tentang Pemberian Air Susu Ibu Eksklusif. Kewajiban memberikan ASI Eksklusif kepada bayi tidak berlaku apabila terdapat hal sebagai berikut: (1) Adanya Indikasi medis; (2) Ibu tidak ada; atau (3) Ibu terpisah dari bayi. Bilamana bayi tidak dapat diberikan ASI secara eksklusif berdasarkan ketiga pertimbangan tersebut, maka memiliki salah satu diantara dua pilihan yaitu diberikan susu formula bayi dan/atau pemberian ASI Ekslusif melalui pendonor ASI.

Yang dimaksud dengan "indikasi medis" adalah kondisi medis Bayi dan/atau kondisi medis ibu yang tidak memungkinkan dilakukannya pemberian ASI eksklusif (Penjelasan Pasal 7 huruf a PP No. 33 Tahun 2012).

Kondisi medis Bayi yang tidak memungkinkan pemberian ASI Eksklusif antara lain: (a) Bayi yang hanya dapat menerima susu dengan formula khusus, yaitu dengan criteria: 1) Bayi dengan galaktosemia klasik, diperlukan formula khusus bebas galaktosa; 2) Bayi dengan 
penyakit kemih beraroma sirup maple (maple syrup urine disease), diperlukan formula khusus bebas leusin, isoleusing, dan valin; dan/atau 3) Bayi dengan fenilketonuria, dibutuhkan formula khusus bebas fenilalanin, dan dimungkinkan beberapa kali menyusui, di bawah pengawasan. (b) Bayi yang membutuhkan makanan lain selain ASI selama jangka waktu terbatas, yaitu: 1) Bayi lahir dengan berat badan kurang dari 1500 (seribu lima ratus) gram (berat lahir sangat rendah); 2) Bayi lahir kurang dari 32 (tiga puluh dua) minggu dari usia kehamilan yang sangat premature; dan/atau 3) Bayi batu lahir yang berisiko hipoglikimia berdasarkan gangguan adaptasi metabolisme atau peningkatan kebutuhan glukosa seperti bayi premature, kecil untuk umur kehamilan atau yang mengalami stress iskemik/intrapartum hipoksia yang signifikan, Bayi yang sakit dan Bayi yang memiliki ibu pengidap diabetes, jika gula darahnya gagal merespons pemberian ASI baik secara langsung maupun tidak langsung (Penjelasan Pasal 7 huruf a PP No. 33 tahun 2012.

Kondisi medis ibu yang tidak dapat memberikan ASI Eksklusif karena harus mendapatkan pengobatan sesuai dengan standar. Kondisi tersebut antara lain: (a) Ibu yang dibenarkan alasan tidak menyusui secara permanen karena terinfeksi Human Immunodeficiency Virus. (b) Ibu yang dapat dibenarkan alasan menghentikan menyusui sementara waktu karena: 1) Penyakit parah yang menghalangi seorang ibu merawat bayi, misalnya sepsis (infeksi demam tinggi hingga tidak sadarkan diri); 2) Infeksi virus Herpes Simplex tipe 1 (HSV-1) di payudara; 3) Pengobatan ibu: a) obatobatan jenis psikoterapi jenis penenang, obat anti epilepsy dan apioid dan kombinasinya dapat menyebabkan efek samping seperti mengantuk dan depresi pernapasan; b) Radioaktif iodine-131 lebih baik dihindari mengingat bahwa alternative yang lebih aman tersedia, seorang ibu dapat melanjutkan menyusui sekitar 2 (dua) bulan setelah menerima zat ini; c) Penggunaan yodium atau yodofor topical misalnya povidone-iodine secara berlebihan, terutama pada luka terbuka atau membran mukosa, dapat menyebabkan penekanan hormone tiroid atau kelainan elektrolit pada bayi yang mendapat ASI harus dihindari; dan d) Sitotoksik kemoterapi yang mensyaratkan seorang ibu harus berhenti menyusui selama terapi (Penjelasan Pasal 7 huruf a PP No.33 Tahun 2012).

Susu Formula Bayi (infant formula milk) menjadi alternatif untuk pemenuhan gizi dalam menumbuh kembangkan pertumbuhan bayi. Namun manfaat dan kualitas gizi dari susu formula tidak lebih baik dari ASI Ekslusif. Sehingga pemerintah menetapkan kebijakan nasional terkait program pemberian ASI Eksklusif sebagai salah satu bentuk tanggung jawab pemerintah.

Bila mana pemberian ASI Ekslusif tidak dimungkinkan berdasarkan pertimbangan sebagai mana dimaksud dalam Pasal 7, maka tenaga kesehatan dalam memberikan Susu Formula Bayi 
Edy Nurcahyo dan Siti Khuzaiyah: Perlindungan hukum bayi melalui pemberian Asi...

harus terlebih dahulu memberikan peragaan dan penjelasan atas penggunaan dan penyajian Susu Formula Bayi kepada ibu dan/atau Keluarga yang memerlukan Susu Formula Bayi.

Dan apabila pemberian susu formula bayi terpaksa harus diberikan dengan berbagai pertimbangan, maka untuk itu tenaga kesehatan wajib memberikan informasi dan edukasi ASI Ekslusif kepada ibu dan/atau anggota keluarga dari Bayi yang bersangkutan. Tujuannya adalah memberikan pemahaman bahwa pemberian ASI secara eksklusif jauh lebih baik daripada pemberian susu formula bayi. Informasi dan edukasi ASI eksklusif diberikan sejak pemeriksaan kehamilan sampai dengan pemberian ASI selesai, tujuan dari edukasi ASI ini untuk memberikan penjelasan keuntungan dan keunggulan pemberian ASI.

Keuntungan dan keunggulan pemberian ASI secara eksklusif yaitu: (1) Mudahnya terjalin ikatan kasih sayang yang mesra antara ibu dan bayi; (2) Bagi bayi, tidak ada pemberian yang lebih berharga dari ASI; (3) ASI dapat meningkatkan kesehatan dan kepandaian bagi bayi secara optimal; (4) ASI juga membuat potensial memiliki emosi yang stabil, spiritual yang matang, serta memiliki perkembangan sosial yang baik (Utami Roesli: 5).

Mengingat keuntungan dan keunggulan pemberian ASI Eksklusif sangat besar, semua pihak harus mendukung pemberian ASI Eksklusif secara optimal, khususnya oleh tenaga kesehatan. untuk mengoptimalkan pemberian ASI Eksklusif secara optimal, tenaga kesehatan dilarang: Memberikan Susu Formula Bayi dan/atau produk bayi lainnya yang dapat menghambat program pemberian ASI Eksklusif kecuali dalam pemberian ASI Eksklusif tidak memungkinkan karena ada indikasi medis, ibu meninggal dunia, atau ibu terpisahkan dari bayinya; (2) menerima dan/atau mempromosikan Susu Formula Bayi dan/atau produk bayi lainnya yang dapat menghambat program pemberian ASI Eksklusif.

Selain larangan yang diberikan kepada Tenaga kesehatan dalam rangka mendukung pemberian ASI Eksklusif secara optimal, juga diberlakukan larangan bagi Penyelenggara Fasilitas Kesehatan, diantaranya yaitu: Penyelenggara Fasilitas Pelayanan kesehatan (PFPK) dilarang memberikan Susu Formula Bayi dan/atau produk bayi lainnya yang dapat menghambat program pemberian ASI Eksklusif kepada ibu bayi dan/atau Keluarganya, kecuali dalam pemberian ASI Eksklusif tidak memungkinkan karena adanya indikasi medis, Ibu meninggal, atau ibu terpisah dari bayinya; (2) Penyelenggara Fasilitas Pelayanan Kesehatan dilarang menerima dan/atau mempromosikan Susu Formula Bayi dan/atau produk bayi lainnya yang dapat menghambat program pemberian ASI Eksklusif. Dan hanya apabila terjadi bencana atau darurat, Penyelenggara Fasilitas Pelayanan Kesehatan dapat menerima bantuan Susu Formula Bayi dan/atau produk bayi lainnya untuk tujuan kemanusiaan setelah mendapat 
persetujuan dari kepala dinas kesehatan kabupaten/kota

setempat;

Penyelenggara Fasilitas Pelayanan Kesehatan dilarang menyediakan pelayanan di bidang kesehatan atas biaya yang disediakan oleh produsen atau distributor Susu Formula Bayi dan/atau produk bayi lainnya.

Selain itu, ada pula larangan bagi Produsen atau Distributor Susu Formula dan/atau produk bayi lainnya dalam rangka mendukung pemberian ASI Eksklusif secara optimal, maka produsen atau distributor dilarang melakukan kegiatan yang dapat menghambat program pemberian ASI Ekslusif berupa: (1) Pemberian contoh produk Susu Formula Bayi dan/atau produk bayi lainnya secara cuma-cuma atau bentuk apapun kepada Penyelenggara Fasilitas Pelayanan Kesehatan, Tenaga Kesehatan, ibu hamil, atau ibu yang baru melahirkan; (2) Penawaran atau penjualan langsung Susu Formula Bayi ke rumah-rumah; (3) Pemberian pertolongan harga atau tambahan atau sesuatu dalam bentuk apapun atas pembelian Susu Formula Bayi sebagai daya tarik dari penjual; (4) Penggunaan Tenaga Kesehatan untuk memberikan informasi tentang Susu Formula Bayi kepada masyarakat; dan/atau (5) Pengiklanan Susu Formula Bayi yang dimuat dalam media massa, baik cetak maupun elektronik, dan media luar ruang.

Peraturan perundang-undangan melakukan larangan pengiklanan Susu Formula Bayi karena dari hasil studi (research) menunjukkan adanya dampak negatif karena akan mempengaruhi perilaku masyarakat untuk menggunakan produk susu formula bayi dan mengesampingkan pemberian ASI Eksklusif.

Apabila Produsen atau distributor tidak melaksanakan ketentuan sebagaimana dimaksud dalam Pasal 19 PP No. 33 tahun 2012 tentang Pemberian ASI Eksklusif akan dikenakan sanksi administratif oleh pejabat yang berwenang berupa: (a) Teguran lisan; dan/atau (b) Teguran tertulis.

Untuk dapat menerapkan sanksi administratif bagi produsen atau distributor Susu Formula Bayi dan/atau produk bayi lainnya yang melakukan kegiatan pengiklanan Susu Formula Bayi yang dimuat dalam media massa, baik cetak maupun elektronik, dan media luar ruang sebagaimana dimaksud dalam pasal 19 huruf e harus dilaksanakan oleh sebuah badan yang melaksanakan tugas pemerintah di bidang pengawasan obat dan makanan (BPOM).

\section{SIMPULAN}

Negara Indonesia telah mengeluarkan serangkaian kebijakan nasional berkaitan dengan perlindungan pemberian ASI Eksklusif terhadap bayi, agar bayi yang berada di seluruh wilayah Indonesia dapat tumbuh dan berkembang menjadi generasi yang sehat dan cerdas. Kebijakan nasional tersebut telah dituangkan dalam bentuk norma, standar, prosedur, dan kriteria yang ditetapkan oleh Menteri. Dan juga strategi program pemberian ASI Eksklusif dilakukan secara terpadu, berjenjang, dan 
Edy Nurcahyo dan Siti Khuzaiyah: Perlindungan hukum bayi melalui pemberian Asi...

berkesinambungan. Dapat disimpulkan pemerintah Indonesia telah mengambil peran tanggung jawab dalam program pemberian ASI Ekslusif secara baik.

Perlindungan hukum yang diberikan dalam program pemberian ASI Eksklusif terhadap bayi yaitu perlindungan hukum publik, bentuk perlindungan yang diberikan adalah perlindungan hukum preventif, yaitu berupa upaya yang diberikan oleh hukum untuk terpenuhinya hak bayi dalam mendapatkan ASI eksklusif agar tercegah dari segala resiko kesehatan.

Indonesia merupakan salah satu Negara yang telah menerapkan International Code of Marketing of Breast-Milk Substitutes melalui kebijakan nasional untuk mendorong terpenuhinya pemberian ASI secara eksklusif. Upaya larangan iklan susu formula bayi baik melalui media cetak ataupun media elektronik dalam rangka mendukung program pemberian ASI Eksklusif secara penuh. Bila hal ini dilanggar akan dikenakan sanksi administratif.

Diperlukan penelitian lebih lanjut mengenai bentuk-bentuk promosi susu formula di lapangan apakah sudah sesuai dengan undang-undang yang berlaku atau belum serta sejauh mana aturan perundang-udangan ditegakkan terhadap perusahaan yang masih mempromosikan susu formula yang melanggar hukum.

\section{UCAPAN TERIMA KASIH}

Penelitian ini terlaksana atas dukungan dari Rektor Universitas Muhammadiyah Buton, Ketua Lembaga
Penelitian dan Pengabdian Masyarakat (LPPM) serta segenap civitas akademika Universitas Muhammadiyah Buton.

\section{DAFTAR PUSTAKA}

\section{Buku-Buku dan Jurnal}

Briawan, Dodik. 2004. Pengaruh Promosi Susu Formula. Makalah Perorangan semester Ganjil. Pps 702: 1-11 http://www.rudyct.com/PPS702ipb/ 09145/dodik briawan.pdf,

http://www.who.int/nutrition/publications/ code_english.pdf

Geme, Maria Teresia, 2008. Perlindungan

Hukum terhadap Masyarakat

Hukum Adat dalam Pengelolaan

Cagar Alam Watu Ata Kabupaten

Ngada, Provinsi Nusa Tenggara

Timur, disertasi Program doctor

Ilmu Hukum Universitas

Diponegoro Semarang

Kemenkes.go.id. 2017. Pemenuhan Gizi

Sejak Dini Tentukan Kualitas

Generasi Penerus Bangsa,

Kemenkes RI: 20-21

(http://www.depkes.go.id/article/vie w/17032900003/pemenuhan-gizi-

sejak-dini-tentukan-kualitas-

generasi-penerus-bangsa-.html)

Kemenkes. 2011. Pentingnya

Pemantauan Kesehatan Pada Masa

Periode Emas,

http://www.depkes.go.id/article/prin t/1597/pentingnya-pemantauan-

kesehatan-pada-masa-periode-emasbalita.html

Kemenkes, Infodatin: Pusat Data dan Informasi Kementerian Kesehatan $R I$, (http://www.depkes.go.id/file://C:/ 
Users/ACER/Downloads/infodatinasi.pdf

Kemenkes, Kemenkes Segera Sempurnakan Regulasi Pemberian ASI, https://lifestyle.kompas.com/read/20 16/06/09/160000423/Kemenkes.Seg era.Sempurnakan.Regulasi.Pemberi an.ASI

Nurlaili Susanti, Peran Ibu Menyusui Yang Bekerja Dalam Pemberian ASI Eksklusif Bagi Bayinya, Jurnal Egalita, Volume 6, No. 1, 2011, h. 165-176

file:///C:/Users/ACER/Downloads/2 122-6106-1-PB.pdf

Prabasiswi, A., Fikawati, S., S., Syafiq, A., 2014. ASI Eksklusif dan Persepsi Ketidakcukupan ASI. Jurnal Kesmas Nasional. 9 (3): file://C:/Users/ACER/Downloads/2 015_ASIEksklusifdanPKA.pdf

Rahardjo, Satijipto, 2000, Ilmu Hukum. PT. Citra Aditya Bakti, Bandung.

Salim HS, Erlies SN, 2013. Penerapan Teori Hukum pada Penelitian Tesis dan Disertasi. Pt. Raja Grafindo Persada, Jakarta.
Utami Roesli, Mengenal ASI Eksklusif, https://books.google.co.id/books?id $=$ zWDmh8QBIkMC\&lpg=PA5\&ots $=\mathrm{UqW}$ cj2P8p3\&dq=keuntungan $\% 2$ 0pemberian\%20ASI\%20eksklusif\& $1 \mathrm{r} \& \mathrm{pg}=\mathrm{PP} 1 \mathrm{H}=$ onepage $\& \mathrm{q}=$ keuntun gan\%20pemberian\%20ASI\%20eksk lusif $\& \mathrm{f}=\mathrm{false}$,

Yenny Fitri, Z. 2018. Tinjauan Hukum Dokter yang Berkolusi dengan Perusahaan Farmasi dalam Meresepkan Obat. Jurnal Cendekia Hukum. 272-282. http://ejurnal.stihpm.ac.id/index.php/cendekeahukum

\section{Peraturan Perundang-Undangan}

Undang-Undang Dasar Negara Republik Indonesia Tahun 1945

Undang-Undang Nomor 36 Tahun 2009 Tentang Kesehatan

Undang-Undang Nomor 35 Tahun 2014 Tentang Perubahan Atas UndangUndang Nomor 23 Tahun 2002 Tentang Perlindungan Anak

Peraturan Pemerintah Nomor 33 Tahun 2012 Tentang Pemberian Air Susu Ibu Eksklusif 